\title{
PENGARUH PELATIHAN DAN MOTIVASI TERHADAP KINERJA KARYAWAN PADA PT PHARMATIA SKIN LAB DEPOK JAWA BARAT
}

\author{
1*Veritia, ${ }^{2}$ Dian Alvita \\ Universitas Pamulang, Tangerang Selatan, Banten, Indonesia \\ *dosen00822@unpam.ac.id
}

\begin{abstract}
Abstrak
Penelitian ini bertujuan untuk mengetahui pengaruh antara pelatihan dan motivasi terhadap Kinerja Karyawan pada PT. Pharmatia Skin Lab Depok, Jawa Barat. Hipotesis penelitian yang diuji adalah terdapat signifikan antara pelatihan dan motivasi terhadap kinerja karyawan padaPT. Pharmatia Skin Lab Depok, Jawa Barat. Metode penelitian yang digunakan dalam penelitian ini adalah metode penelitian kuantitatif, metode sampling yang digunakan adalah sampel jenuh sebanyak 80 karyawan. Teknik pengumpulan data dengan angket, sedangkan metode analisa data yang digunakan uji validitas, uji reliabilitas, uji asumsi klasik, analisis regresi linier sederhana, analisis regresi linier berganda, analisis koefisien korelasi (R), analisis koefisien determinasi, dan pengujian hipotesis. Dari perhitungan analisis regresi linier berganda diperoleh persamaan regresi $Y$ $=16,336+0,085 \times 1+0,303 \times 2$. Berdasarkan hasil penelitian hasil uji t diperoleh thitung untuk pelatihan 3,892 lebih besar dari nilai ttabel 1,990 atau $(3,892>1,990)$ dengan nilai signifikan $0,000<0,05$. Maka dapat disimpulkan bahwa secara parsial pelatihan berpengaruh positif dan signifikan terhadap Kinerja Karyawan. Hal ini berarti bahwa H0 ditolak dan Ha1 diterima. Nilai thitung dari motivasi lebih besar dari ttabel 1,990 atau $(3,011>1,990)$ dengan nilai signifikan 0,003 < 0,05. Maka dapat disimpulkan bahwa secara parsial motivasi berpengaruh positif dan signifikan terhadap kinerja karyawan. Sehingga H02 ditolak dan Ha2 diterima. Untuk uji F diperoleh nilai Fhitung sebesar 5,261 dan signifikan sebesar 0,002 sehingga dapat disimpulkan pelatihan dan motivasi secara simultan berpengaruh positif terhadap kinerja karyawan dibuktikan dengan nilai f hitung 5,261 >f tabel 3,130 dan nilai signifikan 0,002 < 0,05 maka dapat disimpulkan H03 ditolak dan Ha3 diterima.
\end{abstract}

Kata kunci: Pelatihan, Motivasi, Kinerja Karyawan

\begin{abstract}
This study aims to determine the effect of training and motivation on employee performance at PT. Pharmatia Skin Lab Depok, West Java. The research hypothesis tested is that there is a significant relationship between training and motivation on employee performance at PT. Pharmatia Skin Lab Depok, West Java. The research method used in this study is a quantitative research method, the sampling method used is a saturated sample of 80 employees. The data collection technique is a questionnaire, while the data analysis method used is validity test, reliability test, classical assumption test, simple linear regression analysis, multiple linear regression analysis, correlation coefficient analysis (R), coefficient of determination analysis, and hypothesis testing. From the calculation of multiple linear regression analysis, the regression equation $Y=16,336$ $+0,085 \times 1+0,303 \times 2$. Based on the results of the research, the $t$-test results obtained that the tcount for training was 3.892 which was greater than the t-table value of 1.990 or $(3.892>1.990)$ with a significant value of $0.000<0.05$. So it can be concluded that partially training has a positive and significant effect on employee performance. This means that H01 is rejected and Ha1 is accepted. The tcount value of motivation is greater than ttable 1.990 or $(3.011>1.990)$ with a significant value of $0.003<0.05$. So it can be concluded that partially motivation has a positive and significant effect on employee performance. So HO2 is rejected and Ha2 is accepted. For the F test, the Fcount value is 5.261 and a significant value of 0.002 so that it can be concluded that training and motivation simultaneously have a positive effect on employee performance as evidenced by the calculated fvalue of $5.261>$ f table 3.130 and a significant value of $0.002<0.05$, it can be concluded that $\mathrm{HO} 3$ is rejected and Ha3 received.
\end{abstract}

Keywords: Training, Motivation, Employee Performance 


\section{PENDAHULUAN}

\section{Latar Belakang}

Pengelolaan sumber daya manusia diharapkan dapat meningkatkan kemampuan dan motivasi untuk memiliki kinerja yang lebih kompetitif bagi suatu perusahaan/organisasinya. Sumber daya manusia itu menjadi pengelola sumber daya dan penggerak perusahaan untuk menghasilkan produk berkualitas dengan mengkombinasikan antara sumber daya material dan sumber daya manusia. (Hafeez dan Akbar, 2015).

Tentu untuk menghasilkan produk yang berkualitas memerlukan sumber daya manusia yang juga berkualitas. Perusahaan dituntut untuk memperoleh, mengembangkan dan mempertahankan SDM yang berkualitas.

Jika memiliki SDM yang berkualitas, diharapkan tujuan organisasi dalam menghasilkan kinerja karyawan yang optimal tercapai. Untuk mencapai tujuan organisasi dalam hal ini perusahaan harus mampu menciptakan situasi dan kondisi yang mendorong dan memungkinkan karyawan untuk mengembangkan kemampuan dan keterampilan secara maksimal, khususnya dalam hal kinerja.

Menurut Sutrisno (2016:151) kinerja adalah "sebagai hasil yang telah dicapai seseorang dari tingkah kerjanya dalam melaksanakan aktivitas kerja". Karyawan dapat bekerja dengan baik bila memiliki kinerja tinggi, sehingga dapat menghasilkan kinerja yang baik pula.

PT. Pharmatia Skin Lab Depok Jawa Barat yang lebih dikenal dengan Hedtutu Skin Solution, fokus untuk mengembangkan bisnis di klinik kecantikan. Berdasarkan pengamatan awal penelitian PT. Pharmatia Skin Lab Depok Jawa Barat, diindikasikan ada beberapa masalah yang menyebabkan menurunnya kinerja karyawan di perusahaan tersebut. Hal ini bisa dilihat dari table 1. sebagai berikut:

Tabel 1. Rekapitulasi Rata-Rata Hasil Penilaian Kinerja PT. Pharmatia Skin Lab Depok Jawa Barat Periode January 2017 - 0ktober 2020

\begin{tabular}{|c|c|c|c|c|c|c|c|c|c|}
\hline \multirow{2}{*}{ No } & \multirow{2}{*}{ Indikator } & 2017 & \multirow{2}{*}{ Ket. } & 2018 & \multirow{2}{*}{ Ket. } & 2019 & \multirow{2}{*}{ Ket. } & 2020 & \multirow{2}{*}{ Ket. } \\
\hline & & $\%$ & & $\%$ & & $\%$ & & $\%$ & \\
\hline 1. & Kualitas & 71 & Baik & 67 & Cukup & 62 & Cukup & 58 & Cukup \\
\hline 2. & Kuantitas & 71 & Baik & 70 & Cukup & 60 & Cukup & 57 & Cukup \\
\hline 3. & Ketepatan waktu & 80 & Baik & 70 & Cukup & 63 & Sedang & 60 & Cukup \\
\hline 4. & Kerja sama karyawan & 84 & Baik & 83 & Baik & 79 & Baik & 76 & Baik \\
\hline 5. & Penekanan biaya & 85 & Baik & 85 & Baik & 80 & Baik & 73 & Baik \\
\hline 6. & Pengawasan & 85 & Baik & 85 & Baik & 80 & Baik & 75 & Baik \\
\hline & Jumlah & 476 & & 460 & & 424 & & 399 & \\
\hline & Rata-Rata & 79,33 & Baik & 76,66 & Baik & 70,66 & Cukup & 66,5 & Cukup \\
\hline
\end{tabular}

Sumber : PT. Pharmatia Skin Lab Depok Jawa Barat, 2020

Adapun data yang diperoleh mengenai standar penilaian kinerja karyawan adalah sebagai berikut :

Tabel 2. Standar Penilaian Kinerja Karyawan

PT. Pharmatia Skin Lab Depok Jawa Barat

\begin{tabular}{|c|l|c|}
\hline No & \multicolumn{1}{|c|}{ Kategori } & Persentase (\%) \\
\hline $\mathbf{1}$ & Sangat Baik & $86 \%-100 \%$ \\
\hline $\mathbf{2}$ & Baik & $71 \%-85 \%$ \\
\hline $\mathbf{3}$ & Cukup & $57 \%-70 \%$ \\
\hline $\mathbf{4}$ & Buruk & $31 \%-56 \%$ \\
\hline $\mathbf{5}$ & Sangat Buruk & $\leq 27 \%$ \\
\hline
\end{tabular}

Berdasarkan Tabel 2, menurut data di PT. Pharmatia Skin Lab Depok Jawa Barat menjelaskan bahwa standar penilaian di perusahaan dilihat berdasarkan persentase, kinerja yang sangat baik mendapatkan persentase antara $86 \%$ - 100\%, sedangkan kriteria baik mendapatkan persentase sebesar $71 \%$ - 85\% dan kategori sedang mendapatkan persentase $57 \%$ - 70\%. Serta kategori rendah dan sangat rendah berada pada persentase $31 \%-56 \%$ dan dibawah $27 \%$.

Berdasarkan tabel 1, dapat kita lihat bahwa penilaian kinerja terkait Kerjasama, penekanan biaya, pengawasan karyawan sudah baik. Namun untuk kualitas, 
kuantitas, dan ketepatan waktu kerja karyawan dinilai cukup baik. Sehingga jika ditotalkan bisa dikatakan kinerja karyawan PT. Pharmatia Skin Lab Depok selama 3 tahun dari tahun 2017-2020 masih cukup baik. Ini merupakan masalah awal yang ditemukan peneliti.

Faktor yang diduga menyebabkan turunnya kinerja di PT. Pharmatia Skin Lab Depok adalah terkait pelatihan. Menurut

Tabel 3. Pelatihan Karyawan di PT. Pharmatia Skin Lab Depok Jawa Barat

\begin{tabular}{|c|c|c|c|c|c|c|}
\hline \multirow{2}{*}{ No } & \multirow{2}{*}{ Indikator Pelatihan } & \multicolumn{4}{|c|}{ Bobot Penilaian \% } & \multirow{2}{*}{ Bobot Standar \% } \\
\cline { 3 - 5 } & 2017 & 2018 & 2019 & 2020 & \\
\hline 1 & Instruktur & 86,67 & 83,81 & 83,75 & 82,44 & 100 \\
\hline 2 & Peserta Pelatihan & 76,67 & 75,87 & 73,81 & 73,44 & 100 \\
\hline 3 & Materi & 66,67 & 63,99 & 62,75 & 60,07 & 100 \\
\hline 4 & Metode & 73.33 & 72,19 & 70,67 & 69,10 & 100 \\
\hline 5 & Tujuan pelatihan & 89,74 & 88,23 & 88,03 & 87,65 & 100 \\
\hline & Jumlah & 393,08 & 384.09 & 379.01 & 372.7 & \\
\hline & Rata- rata & 78,61 & 76,81 & 75,80 & 74,54 & 100 \\
\hline
\end{tabular}

Sumber : PT. Pharmatia Skin Lab Depok Jawa Barat, 2020
Berdasarkan pengamatan dan wawancara awal dengan karyawan PT. Pharmatia Skin Lab Depok Jawa Barat, terkait indikator materi yaitu instruktur dalam memberikan materi pelatihan tidak dapat dipahami oleh peserta pelatihan.

Selain permasalahan pelatihan, factor lain yaitu masalah motivasi karyawan di PT. Pharmatia Skin Lab Depok Jawa Barat. Motivasi adalah pendorong seseorang melaksanakan suatu kegiatan guna mendapat hasil yang terbaik. Oleh karena itulah tidak heran jika karyawan yang mempunyai motivasi yang tinggi biasanya mempunyai kinerja yang tinggi pula (Dapu, 2015).

Masalah yang ditemukan saat pengamatan dan wawancara awal dengan karyawan di PT. Pharmatia Skin Lab Depok Jawa Barat yaitu, Karyawan masih merasa kurang mendapatkan penghargaan atas prestasinya dan pengakuan atas faktor kemampuan keahliannya.

Permasalahan diatas membuat peneliti tertarik untuk mengkaji lebih dalam apakah terdapat Pengaruh antara Pelatihan dan Motivasi Terhadap Kinerja Karyawan Pada PT. Pharmatia Skin Lab Depok Jawa Barat.
Dessler (2015:284), mengemukakan bahwa "Pelatihan merupakan proses mengajarkan karyawan baru atau yang ada sekarang terkait keterampilan dasar yang mereka butuhkan untuk menjalankan pekerjaan mereka.

Berikut data yang diperoleh mengenai penilaian pelatihan adalah sebagai berikut:
2. Rumusan Masalah

a. Apakah ada pengaruh pelatihan terhadap kinerja karyawan pada PT. Pharmatia Skin Lab Depok, Jawa Barat?

b. Apakah ada pengaruh motivasi terhadap kinerja karyawan pada PT. Pharmatia Skin Lab Depok, Jawa Barat?

c. Apakah ada pengaruh pelatihan dan motivasi terhadap kinerja kayawan pada PT. Pharmatia Skin Lab Depok, Jawa Barat?

\section{Kajian Teoritis Pelatihan}

Menurut Rivai dan Sagala (2009) dalam Sinambela (2017: 169), pelatihan adalah "proses yang sistematis mengubah tingkah laku pegawai untuk mencapai tujuan organisasi, yang berkaitan dengan keahlian dan kemampuan pegawai untuk melaksanakan pekerjaan saat ini".

Sedangkan Dessler (2015:284), mengemukakan bahwa "Pelatihan merupakan proses mengajarkan pegawai baru atau yang ada sekarang, keterampilan dasar yang mereka 
butuhkan untuk menjalankan pekerjaan mereka.

Indikator pelatihan yang digunakan dalam penelitian ini menurut Dessler (2011) dalam Herdiyati dan Suwarsi (2019:279) meliputi: materi pelatihan, peserta pelatihan, metode, instruktur,dan tujuan pelatihan.

\section{Motivasi}

Menurut Afandi (2018:23) motivasi adalah "keinginan yang timbul dari dalam diri seseorang atau individu karena terinspirasi, tersemangati, dan terdorong untuk melakukan aktifitas dengan keikhlasan, senang hati dan sungguh-sungguh sehingga hasil dari aktifitas yang dia lakukan mendapat hasil yang baik dan berkualitas."

Sedangkan menurut Mangkunegara (2017:93), “Motivasi adalah kondisi yang menggerakan pegawai agar mampu mencapai tujuan dari motifnya.

Indikator motivasi yang digunakan adalah teori Maslow dalam Sutrisno (2016:55), meliputi: Kebutuhan fisiologis, kebutuhan rasa aman, kebutuhan sosial, penghargaan dan aktualisasi diri.

\section{Kinerja Karyawan}

Istilah kinerja berasal dari kata Job Performance atau Actual Performance (prestasi kerja atau prestasi sesungguhnya yang dicapai oleh seseorang). Sehingga dapat didefinisikan bahwa kinerja adalah "hasil kerja secara kualitas dan kuantitas yang dicapai oleh seorang pegawai dalam melaksanakan tugasnya sesuai dengan tanggung jawab yang diberikan kepadanya." (Mangkunegara, 2015:67). Sedangkan menurut Kasmir (2016:182) kinerja adalah "hasil kerja dan perilaku kerja yang telah dicapai dalam menyelesaikan tugas-tugas dan tanggung jawab yang diberikan dalam suatu periode tertentu". Adapun indikator yang digunakan menurut Kasmir (2016:208-210) meliputi: kualitas, kuantitas, jangka waktu,
Kerjasama antar karyawan, penekanan biaya, dan pengawasan.

\section{Pengembangan Hipotesis}

a. Apakah ada pengaruh pelatihan terhadap kinerja karyawan pada PT. Pharmatia Skin Lab Depok, Jawa Barat?

Ho1:Diduga pelatihan tidak berpengaruh terhadap Kinerja Karyawan pada PT. Pharmatia Skin Lab Depok, Jawa Barat.

Ha1:Diduga pelatihan berpengaruh terhadap Kinerja Karyawan pada PT. Pharmatia Skin Lab Depok, Jawa Barat .

b. Apakah ada pengaruh motivasi terhadap kinerja karyawan pada PT. Pharmatia Skin Lab Depok, Jawa Barat?

Ho2:Diduga motivasi tidak berpengaruh terhadap Kinerja Karyawan pada PT. Pharmatia Skin Lab Depok, Jawa Barat.

Ha2:Diduga motivasi berpengaruh terhadap Kinerja Karyawan pada PT. Pharmatia Skin Lab Depok, Jawa Barat.

c. Apakah ada pengaruh pelatihan dan motivasi terhadap kinerja karyawan pada PT. Pharmatia Skin Lab Depok, Jawa Barat?

Ho3:Diduga pelatihan dan motivasi tidak berpengaruh terhadap Kinerja Karyawan pada PT. Pharmatia Skin Lab Depok, Jawa Barat.

Ha3:Diduga pelatihan dan motivasi berpengaruh terhadap Kinerja Karyawan pada PT. Pharmatia Skin Lab Depok, Jawa Barat

\section{METODE}

\section{Jenis Penelitian}

Jenis penelitian yang digunakan adalah penelitian kuantitatif. Menurut Yusuf (2016: 58-59) terdapat beberapa ciri-ciri penelitian kuantitatif yang membedakan dengan penelitian lain, diantaranya: menggunakan rancangan 
yang terstruktur, formal dan spesifik. Data dapat dihitung dan terukur, waktu dapat diatur, membutuhkan hipotesis dan analisis data menggunakan statistik

\section{Populasi}

Sugiyono (2017:80) memberikan pengertian populasi adalah "wilayah generalisasi yang terdiri atas: obyek/subyek yang mempunyai kualitas dan karakteristik tertentu yang ditetapkan oleh peneliti untuk dipelajari dan kemudian ditarik kesimpulannya."

Populasi dalam penelitian ini berjumlah 80 yang berlokasi di di PT. Pharmatia Skin Lab Depok Jawa Barat, yang beralamat di Jalan Muchtar Raya RT/03RW/07No 70 Kelurahan Sawangan Baru Kecamatan Sawangan, Sawangan Baru, Kota Depok, Jawa Barat 16511.

\section{Sampel}

Sugiyono (2017:81) juga memberikan pengertian sampel adalah "bagian atau jumlah dan karakteritik yang dimiliki oleh populasi tersebut." Sedangkan Istijanto (2015:111) menyatakan untuk perusahaan kecil dengan jumlah karyawan kurang dari 200 orang, maka penelitian dapat dilakukan dengan metode sensus terhadap semua karyawannya.

Penelitian ini melibatkan seluruh populasi sehingga sampel sama dengan populasi yakni 80 . Jadi penelitian ini menggunakan metode sampel jenuh. Dimana menurut Sugiyono (2017:124) sampling jenuh adalah teknik pengumpulan sampel bila semua anggota populasi digunakan sebagai sampel.

\section{Metode Analisis Data}

Dalam menganalisis data digunakan (1) tehnik analisis data : uji instrumen, uji validitas dan uji reliabiblitas. (2) Uji asumsi klasik: Normalitas, Multikolinieritas, Heteroskedastisitas, Autokorelasi dan Korelasi. (3) Analisis regresi: Regresi Linear Berganda dan Analisis Koefisien Determinasi. (4) pengujian Hipotesis: Uji t dan Uji F.

\section{HASIL DAN PEMBAHASAN}

\section{HASIL}

\section{Analisis Regresi Linier Berganda}

Berdasarkan hasil uji asumsi klasik yang telah dilakukan, diketahui bahwa model regresi dalam penelitian ini layak untuk digunakan karena telah terbebas dari masalah normalitas data, tidak terjadi multikolonieritas, heteroskedaksitas, dan autokorelasi. Langkah selanjutnya yaitu melakukan analisis regresi linier berganda. Analisis regresi linier berganda memiliki tujuan untuk menguji pengaruh variabel independen yaitu pelatihan, dan motivasi terhadap variabel dependen

Yaitu kinerja.

Hasil uji analisis regresi linier berganda dapat dilihat pada tabel sebagai berikut:

Tabel 4.Hasil Uji Analisis Regresi Linier Berganda

\begin{tabular}{|l|r|r|r|r|r|}
\hline \multirow{2}{*}{ Model } & \multicolumn{2}{|c|}{ Unstandardized Coefficients } & Standardized Coefficients & & \\
\cline { 2 - 5 } & \multicolumn{1}{|c|}{$\mathrm{B}$} & Std. Error & Beta & \multicolumn{1}{c|}{ S } & Sig. \\
\hline 1 (Constant) & 16,336 & 4,852 & & 2,893 &, 000 \\
PELATIHAN &, 085 &, 095 &, 386 & 3,892 &, 000 \\
MOTIVASI &, 303 &, 101 &, 287 & 3,011 &, 003 \\
\hline
\end{tabular}

Sumber: Data SPSS 23.0 diolah, 2020

Dari perhitungan regresi yang telah diolah pada tabel 4.16, diperoleh persamaan regresi $\mathrm{Y}=16,336+$ $0,085 \times 1+0,303 \times 2$ dari persamaan diatas ,maka disimpulkan bahwa: a. Nilai constanta (a) 16,336 diartikan bahwa variabel pelatihan (X1) dan motivasi (X2) tidak ada, maka telah terdapat nilai kinerja karyawan $(\mathrm{Y})$ sebesar 16,336. Artinya karyawan 
akan tetap menghasilkan kinerja walaupun pelatihan dan motivasi yang diberikan masih kurang, karena pada dasarnya karyawan sudah memberikan kinerjanya pada perusahaan tersebut.

b. Nilai pelatihan (X1) sebesar 0,085 diartikan bahwa apabila konstanta tetap dan tidak ada perubahan pada variabel motivas kerja $(X 2)$, maka setiap perubahan 1 unit pada variabel pelatihan (X1) akan mengakibatkan terjadinya perubahan pada kinerja karyawan sebesar (Y) sebesar 0,085 point

c. Nilai motivasi (X2) sebesar 0,303 diartikan bahwa apabila konstanta tetap dan tidak ada perubahan pada variabel pelatihan (X1), maka setiap perubahan 1 unit pada variabel motivasi (X2) akan mengakibatkan terjadinya perubahan pada kinerja karyawan sebesar (Y) sebesar 0,303 point.

\section{Hasil Uji Koefisien Korelasi}

Analis koefisien korelasi dimaksudkan untuk mengetahui tingkat kekuatan hubungan antara variabel independen terhadap variabel dependen. Berikut adalah tabel pedoman intepretasi dari koefisien korelasi dapat dilihat pada tabel 5 DAN hasil uji korelasi dari setiap variabel independen $(X)$ terhadap variabel dependen $(Y)$ : berikut ini:

Tabel 5. Interpretasi Koefisien Korelasi

\begin{tabular}{|c|c|c|}
\hline No & Interval Koefisien & Tingkat Hubungan \\
\hline 1 & $0,000-0,199$ & Sangat Rendah \\
\hline 2 & $0,200-0,339$ & Rendah \\
\hline 3 & $0,400-0,599$ & Sedang \\
\hline 4 & $0,600-0,799$ & Kuat \\
\hline 5 & $0,800-1,000$ & Sangat Kuat \\
\hline
\end{tabular}

Sumber : Dari Sugiyono (2015:47)
Tabel 6. Hasil Analisis Koefisien Korelasi Antara Pelatihan (X1) Terhadap Kinerja Karyawan (Y)

Correlations

\begin{tabular}{|ll|r|r|}
\hline & \multicolumn{1}{|c|}{ Pelatihan } & kinerja \\
\hline \multicolumn{2}{|c|}{ Pearson correlation } & 1 & $.632^{* *}$ \\
Pelatihan & Sig. (2 & & .000 \\
& tailed) & & \\
& $\mathrm{N}$ & 80 & 80 \\
& Pearson & $.632^{* *}$ & 1 \\
Kinerja & corelation & & \\
& Sig. (2- & .000 & \\
& tailed) & 80 & 80 \\
\hline
\end{tabular}

Sumber: Data SPSS 23.0 diolah, 2020

Berdasarkan hasil pengujian pada tabel 6. diatas, maka di peroleh nilai $\mathrm{R}$ (koefisien korelasi) sebesar 0,632 dan mempunyai arti bahwa variabel pelatihan (X1) dan kinerja karyawan (Y) mempunyai tingkat hubungan yang "Kuat", karena nilai 0.632 berada diantara 0,600 - 0,799.

Berikut ini ditampilkan tabel dari hasil uji korelasi dari setiap variabel independen $(X)$ terhadap variabel dependen (Y). Dapat dilihat pada tabel 7 berikut.

Tabel 7. Hasil Analisis Koefisien Korelasi Antara Motivasi (X2) Terhadap Kinerja Karyawan $(\mathrm{Y})$ Correlations

\begin{tabular}{|lc|c|r|}
\hline & & Motivasi & Kinerja \\
\hline \multicolumn{2}{|l|}{ Pearson correlation } & 1 & $.569^{* *}$ \\
Motivasi & Sig. (2-tailed) & & .000 \\
& $\mathrm{~N}$ & 80 & 80 \\
& Pearson corelation & $.569^{* *}$ & 1 \\
Kinerja & Sig. (2-tailed) & .000 & \\
& $\mathrm{~N}$ & 80 & 80 \\
\hline
\end{tabular}

Sumber: Data SPSS 23.0 diolah, 2020

Berdasarkan hasil pengujian pada tabel 7. diatas, maka di peroleh nilai $\mathrm{R}$ (koefisien korelasi) sebesar 0,569 dan mempunyai arti bahwa variabel motivasi (X2) dan kinerja karyawan (Y) mempunyai tingkat hubungan yang "Sedang", karena nilai 0.569 berada diantara 0,40 - 0,599.

Berikut ini ditampilkan tabel dari hasil uji korelasi dari setiap variabel independen (X1) independen 
terhadap variabel dependen (Y). Dapat

dilihat pada tabel 8 berikut:

Tabel 8.

Hasil Analisis Koefisien Korelasi Antara

Pelatihan (X1) dan Motivasi (X2) Terhadap Kinerja Karyawan (Y)

Correlations

\begin{tabular}{|c|c|c|c|c|c|}
\hline $\begin{array}{c}\text { Mode } \\
\mathrm{I}\end{array}$ & $\mathrm{R}$ & $\begin{array}{c}\mathrm{R} \\
\text { Squar } \\
\mathrm{e}\end{array}$ & $\begin{array}{c}\text { Adjuste } \\
\mathrm{d} \mathrm{R} \\
\text { Square }\end{array}$ & $\begin{array}{c}\text { Std. } \\
\text { Error of } \\
\text { the } \\
\text { Estimat } \\
\mathrm{e}\end{array}$ & $\begin{array}{c}\text { Durbin } \\
- \\
\text { Watso } \\
\mathrm{n}\end{array}$ \\
\hline 1 & $\begin{array}{c}\mathrm{T} \\
\mathrm{a}\end{array}$ &, 518 &, 509 & 3,24957 & 1,852 \\
\hline
\end{tabular}

Sumber: Data SPSS 23.0 diolah, 2020

a. Predictors: (Constant), PELATIHAN, MOTIVASI

b. Dependent Variable: KINERJA

Berdasarkan hasil pengujian pada tabel 8 diatas, maka diperoleh nilai $\mathrm{R}$ (koefisien korelasi) sebesar 0,718 dan mempunyai arti bahwa variabel pelatihan(X1) dan motivasi (X2) terhadap kinerja karyawan (Y) mempunyai tingkat hubungan yang "Kuat" karena nilai 0,718 beradadiantar a 0,600 0,799 .

\section{Koefisien Determinasi}

Tabel 9.

Hasil Uji Analisis Koefisien Penentu

\begin{tabular}{l|r|r|r|c|}
\hline Model & $\mathrm{R}$ & R Square & $\begin{array}{c}\text { Adjusted R } \\
\text { Square }\end{array}$ & $\begin{array}{c}\text { Std. Error of the } \\
\text { Estimate }\end{array}$ \\
\hline 1 &, $376^{\mathrm{a}}$ &, 141 &, 114 & 3,06462 \\
\hline
\end{tabular}
Sumber: Data SPSS 23.0 diolah, 2020
a. Predictors: (Constant), PELATIHAN, MOTIVASI
b. Dependent Variable: KINERJA

Berdasarkan tabel 9 diatas diperoleh nilai $\mathrm{R}$ square, sebesar 0,141 atau $(14,1 \%)$. Hal ini menunjukan bahwa presentase pengaruh pelatihan dan motivasi, terhadap kinerja karyawan berdasarkan adalah sebesar $14,1 \%$.

Dengan kata lain variabel pelatihan dan motivasi adalah sebesar $14,1 \%$ sedangkan sisanya sebesar $85,9 \%$

Tabel 10. Hasil Uji Hipotesis (Uji T) Variabel Pelatihan (X1) terhadap Kinerja Karyawan (Y)

\begin{tabular}{|l|r|r|r|r|r|}
\hline \multirow{2}{*}{ Model } & \multicolumn{2}{|c|}{$\begin{array}{c}\text { Standardized } \\
\text { Coefficients }\end{array}$} & \multicolumn{1}{|c|}{} \\
\cline { 2 - 4 } & \multicolumn{2}{|c|}{ Unstandardized Coefficients } & \multicolumn{1}{c|}{ S } & \multicolumn{1}{c|}{ Sig. } \\
\hline (Constant) & 16,336 & 4852, & & 2,893 &, 000 \\
PELATIHAN &, 085 &, 095 &, 386 & 3,892 &, 000 \\
MOTIVASI &, 303 &, 101 &, 287 & 3,011 &, 003 \\
& & & & & \\
\hline
\end{tabular}

Sumber: Data SPSS 23.0 diolah, 2020

Berdasarkan hasil pengujian pada tabel 10. diatas, maka diperoleh nilai thitung $>$ ttabel sebesar 3,892 $>1,990$ dan hal itu diperkuat dengan nilai $p$ value $<0,05$ sebesar $0,000<0,05$. Dengan demikian maka H01 ditolak dan Ha2 diterima, hal ini menunjukan bahwa terdapat pengaruh yang positif dan signifikan secara parsial antara pelatihan terhadap kinerja karyawan pada PT. Pharmatia Skin Lab Depok Jawa Barat Depok.

2) Pengaruh motivasi (X2) terhadap kinerja karyawan (Y) Dapat dilihat pada tabel 11 berikut: 
Tabel 11. Hasil Uji Hipotesis (Uji t) Variabel motivasi (X2) terhadap Kinerja Karyawan (Y)

\begin{tabular}{|c|c|c|c|c|c|}
\hline \multirow[b]{2}{*}{ Model } & \multicolumn{2}{|c|}{ Unstandardized Coefficients } & \multirow{2}{*}{$\begin{array}{c}\text { Standardized } \\
\text { Coefficients } \\
\text { Beta }\end{array}$} & \multirow[b]{2}{*}{$\mathrm{t}$} & \multirow[b]{2}{*}{ Sig. } \\
\hline & $\mathrm{B}$ & Std. Error & & & \\
\hline (Constant) & 16,336 & 4852 & & 2,893 & ,000 \\
\hline PELATIHAN & ,085 & ,095 & ,386 & 3,892 & ,000 \\
\hline MOTIVASI & ,303 & ,101 & ,287 & 3,011 & ,003 \\
\hline
\end{tabular}

Sumber: Data SPSS 23.0 diolah, 2020

Berdasarkan hasil pengujian pada tabel 11. diatas, maka diperoleh nilai thitung > ttabel sebesar 3,011 > 1,990 dan hal itu diperkuat dengan nilai $\mathrm{p}$ value $<0,05$ sebesar $0,003<$ 0,05 .

Dengan demikian maka H02

menunjukan bahwa terdapat pengaruh yang positif dan signifikan secara parsial antara motivasi terhadap kinerja karyawan pada PT. Pharmatia Skin Lab Depok Jawa Barat Depok. ditolak dan $\mathrm{Ha} 2$ diterima, hal ini

3) Pengaruh Pelatihan (X1) dan Motivasi (X2) Terhadap Kinerja (Y)

Tabel 12.Hasil Hipotesis (Uji F) Secara Simultan Antara Pelatihan (X1) Dan Motivasi (X2) Terhadap Kinerja Karyawan (Y).

\section{ANOVA}

\begin{tabular}{|l|r|r|r|c|c|}
\hline Model & Sum of Squares & Df & Mean Square & $F$ & Sig. \\
\hline 1 Regression & 148,218 & 2 & 49,406 & 5,261 &, $002^{\mathrm{b}}$ \\
Residual & 901,622 & 96 & 9,392 & & \\
Total & 1049,840 & 99 & & & \\
\hline
\end{tabular}

Sumber: Data SPSS 23.0 diolah, 2020

a. Dependent Variable: kinerjakaryawan

b. Predictors: (Constant), Pelatihan, Motivasi

Berdasarkan hasil pengujian pada tabel 12 diatas, maka diperoleh nilai fhitung > ftabel sebesar 5,261 > 3,130 dan hal itu diperkuat dengan nilai $\mathrm{p}$ value $<$ Sig. 0,05 sebesar 0,002 $<0,05$. Dengan demikian maka H03 ditolak dan $\mathrm{Ha} 3$ diterima, hal ini menunjukan bahwa terdapat pengaruh yang positif signifikan secara simultan antara pelatihan dan motivasi terhadap kinerja karyawan pada PT. Pharmatia Skin Lab Depok Jawa Barat Depok.

\section{PENUTUP}

\section{Simpulan}

a. Pelatihan berpengaruh positif signifikan terhadap kinerja karyawan PT. Pharmatia Skin Lab Depok, Jawa Barat. Berdasarkan hasil uji regresi berganda secara parsial, diperoleh nilai thitung $>$ ttabel sebesar 3,892 >1,990 diperkuat dengan nilai $p$ value $<$ Sig. sebesar 0,00 $<0,05$. Dengan demikian maka H01 ditolak dan Ha1 diterima, hal ini menunjukan bahwa terdapat pengaruh yang positive dan signifikan secara parsial antara pelatihan terhadap kinerja karyawan.

b. Motivasi berpengaruh positif signifikan terhadap kinerja karyawan PT. Pharmatia Skin Lab Depok, Jawa Barat. Berdasarkan hasil uji regresi berganda secara parsial, diperoleh nilai thitung $>$ ttabel sebesar 3,011 > 1,990 diperkuat dengan nilai $p$ value $<$ Sig sebesar $0,03<$ 0,05 . Dengan demikian maka H02 ditolak dan Ha2 diterima, hal ini menunjukan bahwa terdapat pengaruh yang positive dan signifikan secara parsial antara motivasi terhadap kinerja karyawan.

c. Pelatihan dan motivasi berpengaruh positif signifikan terhadap kinerja karyawan PT. Pharmatia Skin Lab 
Depok, Jawa Barat. Berdasarkan hasil uji regresi berganda secara simultan, diperoleh nilai thitung $>$ ttabel sebesar $5,261>3,130$ diperkuat dengan nilai $p$ value $<$ Sig. sebesar 0,02<0,05. Dengan demikian maka H03 ditolak dan Ha3 diterima, hal ini menunjukan bahwa terdapat pengaruh yang positive dan signifikan secara simultan antara pelatihan dan motivasi terhadap kinerja karyawan.

\section{Saran}

a. Kemajuan perusahaan berkaitan dengan pengembangan SDM dimana pelatihan karyawan merupakan hal penting dari kegiatan tersebut. Maka sebaiknya PT. Pharmatia Skin Lab Depok lebih memperbaiki dari sisi materi dan instruktur pelatihan. Isi dan topik materi dibuat sesuai kebutuhan dan semenarik mungkin. Serta instruktur di pilih yang bisa menyampaikan materi yang menarik dan menguasai komunikasi dengan baik. Sehingga peserta selalu semangat dalam mengikuti pelatihan.

b. Tanpa ada motivasi karyawan, tujuan perusahaan dapat tidak tercapai. Oleh karena itu PT. Pharmatia Skin Lab Depok sebaiknya mempertimbangkan bonus sebagai salah satu penghargaan sesuai dengan hasil kinerja karyawan. Peran atasan dalam memberikan semangat terutama bantuan ketika karyawan kesulitan juga dibutuhkan.

c. Kinerja karyawan dapat terhambat jika tidak dilengkapi dengan alat operasional yang memadai. Maka sebaiknya PT. Pharmatia Skin Lab Depok menambah fasilitas kerja karyawan terutama yang berkaitan dengan alat kerja guna mendukung kelancaran operasional perusahaan.

\section{DAFTAR PUSTAKA}

Afandi, P. (2018). Manajemen Sumber Daya Manusia. Riau: Zanafa Publishing.

Ajimat, A., \& Maolana, A. (2020). Pengaruh

Pelatihan Terhadap Kinerja Pegawai

Divisi Antaran PT Pos Indonesia
(Persero) Ciputat. Jurnal Disrupsi Bisnis, 3(1), 115-134.

Akbar, I. R., Prasetiyani, D., \& Nariah, N. (2020). Pengaruh Motivasi Terhadap Kinerja Karyawan Pada Pt. Unggul Abadi Di Jakarta. Jurnal Ekonomi Efektif, 3(1).

Dapu, V. A. W. (2015). The influence of work discipline, leadership, and motivation on Employee performance at PT. Trakindo utama manado. Jurnal EMBA: Jurnal Riset Ekonomi, Manajemen, Bisnis dan Akuntansi, 3(3).

Dessler, G. (2015). Manajemen Sumber Daya Manusia. Jakarta: Salemba Empat.

Hafeez, U \& Akbar, W. (2015). Impact of Training on Employees Performance (Evidence from Pharmaceutical Companies in Karachi, Pakistan). Journal of Business Management and Strategy. Vol. 6. No. 1. ISSN: 21576068.

Hartomo, N. K., \& Luturlean, B. S. (2020). Pengaruh Pelatihan Terhadap Kinerja Karyawan Kantor Pusat PT. Pos Indonesia (Persero) Bandung. Jurnal Ilmiah MEA (Manajemen, Ekonomi, \& Akuntansi), 4(1), 200-207.

Hermawati, R., Firdaus, A., Suryani, N. L., Rozi, A., \& Erlangga, H. (2021). Pengaruh Pelatihan Dan Motivasi Terhadap Kinerja Karyawan Pada Bank BJB di Cabang Balaraja Banten. JENIUS (Jurnal Ilmiah Manajemen Sumber Daya Manusia), 4(3), 319-331.

Herdiyati, S. D., \& Suwarsi, S. (2019). Pengaruh Pelatihan terhadap Kompetensi Kewirausahaan pada PMI Purna di Kabupaten Majalengka. Istijanto, (2015). Riset Sumber Daya Manusia. Jakarta: Gramedia Pustaka.

Kristianti, L. S., et al (2021). Pengaruh Motivasi Dan Disiplin Kerja Terhadap Kinerja Pegawai Pada Dinas Pariwisata Purwakarta. Jurnal Ilmiah PERKUSI, 1(1), 101-109.

Julianry, A., Syarief, R., \& Affandi, M. J. (2017). Pengaruh pelatihan dan 
motivasi terhadap kinerja karyawan serta kinerja organisasi kementerian komunikasi dan informatika. Jurnal Aplikasi Bisnis dan Manajemen (JABM), 3(2), 236-236.

Kasmir. (2016). Manajemen Sumber Daya Manusia (Teori dan Praktik). Depok: PT Rajagrafindo Persada.

Mangkunegara, A. P. (2017). Manajemen Sumber Daya Manusia Perusahaan, Cetakan Kesepuluh, Bandung: PT. Remaja Rosdakarya Offset.

Mangkunegara, A. P. (2017). Evaluasi Kinerja SDM (Edisi Kede). Bandung: Refika Aditama.

Mangkunegara, A. P. (2015). Manajemen Sumber Daya Manusia Perusahaan. PT Remaja Rosdakarya, Bandung.

Noratta, S., \& Prabowo, B. (2019). Pengaruh Pelatihan Dan Motivasi Terhadap Kinerja Karyawan PT. Timur Raya Lestari. Jurnal Ekonomi Efektif, 1(3).

Septiadi, M. D., Marnisah, L., \& Handayani, S. (2020). Pengaruh Motivasi terhadap Kinerja Karyawan PT Brawijaya
Utama Palembang. JASMARK: Jurnal Manajemen Sumber Daya Manusia, Pemasaran dan Keuangan, 1(1), 1-8.

Sinambela, L. P. (2017). Manajemen Sumber Daya Manusia. Jakarta: Bumi. Aksar.

Sugiyono. (2017) Metode Penelitian Kuantitatif, Kualitatif dan R\&D. Jakarta: Alfabeta.

Sugiyono (2015). Metode Penelitian Kombinasi (Mix Methods). Bandung: Alfabeta.

Sunarsi, D., (2017). Pengaruh Kepemimpinan Dan Budaya Organisasi Terhadap Kinerja Karyawan Pada Bank Dki Cabang Pembantu Pondok Labu-Jakarta Selatan. JENIUS (Jurnal Ilm. Manaj. Sumber Daya Manusia), 1(1), 22-51.

Sutrisno, E. (2016). Manajemen Sumber Daya Manusia, Kencana Prenada. Jakarta: Media Group.

Yusuf, A. M. (2016). Metode penelitian kuantitatif, kualitatif \& penelitian gabungan. Prenada Media. 